\title{
Banking Activities and Local Output Growth: Does Distance from Centre Matter?
}

\section{Süheyla Özyildirim \& Zeynep Önder}

To cite this article: Süheyla Özyildirim \& Zeynep Önder (2008) Banking Activities and Local Output Growth: Does Distance from Centre Matter?, Regional Studies, 42:2, 229-244, DOI: 10.1080/00343400601142829

To link to this article: http://dx.doi.org/10.1080/00343400601142829

曲 Published online: 11 Mar 2008.

Submit your article to this journal

Џll Article views: 184

Q View related articles $₫$

4 Citing articles: 10 View citing articles $ત$ 


\title{
Banking Activities and Local Output Growth: Does Distance from Centre Matter?
}

\author{
SÜHEYLA ÖZYILDIRIM and ZEYNEP ÖNDER \\ Faculty of Business Administration, Bilkent University, Bilkent, Ankara 06800, Turkey.Emails: suheyla@bilkent.edu.tr and \\ zonder@bilkent.edu.tr
}

(Received March 2006: in final form October 2006)

ÖZyildirim S. and Önder Z. Banking activities and local output growth: does distance from centre matter? Regional Studies. In this paper the relation between local banking activities and local output growth is empirically studied in Turkey during the period 1991-2000. Although there is no legal restriction against regional banking, the banking sector is spatially concentrated in Turkey. In this institutional structure, the distance between headquarters and the local branches is argued to affect the role of financial intermediation in the development of provincial prosperity. Empirical findings suggest that banking activities have a significant positive impact on the per capita local output growth of regions, especially on those that are distant from the financial centre. However, when bank loans are adjusted to the size of the local economy (provincial gross domestic product, GDP), the relation between banking activities and the output per capita is found to be negative, suggesting that these loans are used to finance unprofitable and unproductive projects in distant provinces.

Local growth Banking activities Distance Financial centre

ÖZYILDIRIM S. and ÖNDER Z. 银行业活动和本地的产量增长: 离中心的距离是否重要? 区域研究。这篇文章对土耳其 1991 年到 2000 年间本地银行业活动和本地产量增长之间的关系进行了经验研究。虽然区域的银行业在法律上并没 有受到限制，土耳其的银行业仍然出现了地理集中。我们讨论了在这个体制结构中，总行和地方支行之间的距离 影响了在省区繁荣发展过程中金融中介的作用。经验研究结果发现, 银行业活动对地区的人均产量增长有显著的 积极影响，尤其是那些远离金融中心的区域。然而，当根据本地经济规模（全省国内生产总值, GDP）对银行贷 款进行调整时，我们发现银行业活动与人均产量之间的关系变成消极的，说明了在边远的省区这些贷款被用于金 融上没有效益的项目。

地方增长银行业活动距离金融中心

ÖZYILDIRIM S. et ÖNDER Z. Les activités bancaires et la croissance de la production locale: la distance du centre, importe-t-elle? Regional Studies. Cet article cherche à étudier empiriquement pour la Turquie le rapport entre les activités bancaires et la croissance de la production locale entre 1991 et l'an 2000. Bien que il n'y ait aucun obstacle juridique aux opérations bancaires régionales en Turquie, le secteur bancaire est concentré géographiqement. Vu cette structure institutionnelle, on affirme que la distance entre le siège social et les agences locales influe sur le rôle de l'intermédiation financière dans le développement de la prospérité régionale. Les preuves empiriques laissent supposer que les activités bancaires ont un impact positif non-négligeable sur la croissance de la production locale par tête des régions, notamment sur celles qui sont loin du noyau financier. Cependant, une fois ajusté les prêts bancaires pour tenir compte de la taille de l'économie locale (PIB régional), le rapport entre les activités bancaires et la production par tête s'avère négatif, ce qui laisse supposer que ces prêts servent à financer des projets non rentables et improductifs lancés dans des régions lointaines.

Croissance locale Activités bancaires Distance Noyau financier

ÖZyildirim S. und Önder Z. Bankaktivitäten und lokales Produktionswachstum: Spielt die Entfernung vom Zentrum eine Rolle? Regional Studies. In diesem Beitrag wird der Zusammenhang zwischen lokalen Bankaktivitäten und lokalem Produktionswachstum in der Türkei im Zeitraum von 1991 bis 2000 empirisch untersucht. Obwohl das regionale Bankwesen in der Türkei keiner gesetzlichen Einschränkung unterliegt, ist der Banksektor räumlich konzentriert. In dieser institutionellen Struktur wirkt sich die Entfernung zwischen der Zentrale und den Filialen nach unserer Argumentation auf die finanzielle Vermittlungsrolle bei der Entwicklung des Wohlstands in den Provinzen aus. Die empirischen Ergebnisse lassen darauf schließen, dass sich die Bankaktivitäten deutlich positiv auf das Wachstum der lokalen Pro-Kopf-Produktion in den Regionen auswirken, insbesondere in Regionen, die weit entfernt vom Finanzzentrum liegen. Wenn wir jedoch die Bankdarlehen an die Größe der lokalen Wirtschaft anpassen (BIP in der Provinz), erweist sich die Beziehung zwischen den Bankaktivitäten und der Pro-Kopf-Produktion als negativ, was darauf schließen lässt, dass diese Darlehen in abgelegenen Provinzen zur Finanzierung von unrentablen und unproduktiven Projekten genutzt werden.

Lokales Wachstum Bankaktivitäten Entfernung Finanzzentrum 
ÖZYildirim S. y ÖNDER Z. Actividades bancarias y crecimiento económico local: ¿Es importante la distancia del centro? Regional Studies. En este artículo analizamos empíricamente la relación entre las actividades bancarias y el crecimiento económico a nivel local en Turquía durante el periodo de 1991 a 2000. Aunque no existe una limitación legal contra la banca regional, en Turquía el sector bancario está concentrado espacialmente. Según nuestra argumentación, en esta estructura institucional la distancia entre las sedes centrales y las sucursales locales afecta al rol de la intermediación financiera en el desarrollo de la prosperidad provincial. Los resultados empíricos indican que las actividades bancarias tienen una influencia muy positiva en el crecimiento económico local per cápita en las regiones, especialmente en las que están más alejadas del centro financiero. Sin embargo, cuando ajustamos los préstamos bancarios al tamaño de la economía local (PIB provincial), observamos que la relación entre las actividades bancarias y el rendimiento per cápita es negativa lo que sugiere que estos préstamos se utilizan para financiar proyectos no rentables e improductivos.

Crecimiento local Actividades bancarias Distancia Centro financiero

JEL classifications: G21, O16, O40, R12

\section{INTRODUCTION}

A number of recent studies have shown that financial intermediation plays an important role in economic growth. These studies provide strong evidence of the relationship between financial development and growth at the firm level, industry level and crosscountry level. ${ }^{1}$ Nonetheless, the existing theoretical and empirical works have not emphasized the link between financial services and growth at the regional level. Recently, Guiso et al. (2004) and HaO (2003) showed that provincial financial development significantly promoted regional growth in Italy and China. The paucity of research on the relationship between provincial and financial development is partly due to the assumption that financial capital is perfectly mobile among regions and thus plays a passive role in regional growth. However, the analyses by ROBERTS and Fishrind (1979), Moore and Hill (1982), Dow (1987), Hutchinson and McKillop (1990), HARrigan and MCGREgor (1997), Amos and Wingender (1993) and GREENWALd et al. (1993) show that financial activities have a spatial dimension and that capital is immobile in practice. The main argument in these studies is the existence of informational imperfections that create conditions under which regional interest rates may diverge from the national rates. Another line of literature emphasizes the existence of institutional segmentation that creates a spatially centralized financial system under which capital flows disproportionately among regions, although financial institutions do not compete on price (Dow, 1987; Hutchinson and McKillop, 1991; Gentle, 1993; Martin and Minns, 1995; Porteous, 1995, 1999; and Klagge and Martin, 2005). This paper provides further evidence about the relationship between financial intermediation and regional economic growth by taking into consideration the spatial dimension of financial capital. More precisely, we test whether local banking activities spur per capita output growth using data from provinces in Turkey where there are no regional banks.
The formation of big banks through the consolidations and mergers of smaller banks has been widely observed in the banking sector in many countries. Although this trend may improve the operating efficiency of banks by exporting superior managerial skills, policies and procedures, the impact of the changing organizational structure of banks on local development has not been resolved theoretically and empirically. Yet, it can be argued that banks with centralized or hierarchical organization may hinder the positive impact of financial intermediation on economic growth. For example, decentralized or regional small banks are situated locally, near the consumers, whereas centralized large banks approach their clients by means of a network of branch offices or alternative distribution channels and establish local decision-making procedures that guarantee quick but satisficing rather than optimizing solutions. ${ }^{2}$ Moreover, centralized large banks may have limited information about local investment opportunities. As a result, these banks may reject profitable local investment opportunities or use scarce resources in unproductive local investments (MARTIN and MINNS, 1995; Alessandrini and Zazzaro, 1999; Klagge and MARTin, 2005). Furthermore, local branch managers may lower the necessary monitoring mechanisms on loans that are approved by the head offices. Thus, as the distance between bank executives and local branch managers or among contracting parties increases, the agency problems might be exacerbated (PORTEOUs, 1995; Berger and Deyoung, 2001).

Nevertheless, a centralized banking organization may have a positive impact on local growth. The credit decisions made at the centre are usually based on hard rather than soft information (BERGER et al., 2005). Hard information is quantitative and easy to store and transmit in an impersonal way across physical distances, and its content is independent of its collection process. Decisions made using this information usually results in granting credits to realistically high return projects. As a result, the available funds could be allocated to productive investment opportunities at the national 
level. However, this allocation may result in divergencies in regional development (PORTEOUs, 1995; McPherson and Waller, 2000; Klagge and MARTIN, 2005). We analyze how the geographical concentration of banks' head offices influences local welfare in this paper. More precisely, we examine whether or not the distance between the geographically concentrated decision centre of banks and the local branches affects the relation between financial intermediation and regional economic growth.

Turkey provides a unique setting to analyze the dual role of distance and centralized institutional structure in regional growth. Unlike many European countries, the USA, or Japan, where there are a large number of comparatively small and locally based banks, Turkey has no regional banks. ${ }^{3}$ The decision centres or headquarters of all private banks are located in one province, Istanbul (the financial centre). Banks operate through several branches located in different provinces throughout the country. Obviously, the centralized institutional structure of the Turkish banking system affects the provision of local banking services. In this structure, the findings of this paper would also provide evidence for understanding the effects of global banking on local economies. To our knowledge, the current study is the first to consider the interaction between the physical distance and the impact of banking services on local growth.

The results of the empirical analysis of Turkish provinces over the period 1991-2000 show that financial intermediation had a significant impact on local economic growth, controlling for other regional and macroeconomic factors. In line with the findings of cross-country studies, we observe a positive and significant effect of local loan provisions on per capita local output growth in Turkey. However, this relation between bank loans and the well-being of the local economy changed significantly when the geographical location of the provinces is taken into consideration. More precisely, we find that, in absolute terms, increasing loan provisions to distant provinces contribute further to the per capita income of those provinces. Because provinces closer to the financial centre are better developed, economically and socially, than are those far away, it is observed that the additional provision of bank loans to distant provinces increases local growth rates further. However, when we adjust bank loans to the size of the local economy (provincial GDP), the increase in the banking activities is found to be associated with the lower levels of output per capita, suggesting that these loans are used to finance unprofitable and unproductive projects in distant provinces.

The next section of this paper summarizes the theoretical and empirical models that examine the relationship between financial development and economic growth and provides background information about the Turkish banking system. The empirical model and the hypotheses are presented in the third section. The fourth section presents the results of the analysis. The final section concludes the paper with some policy implications.

\section{BACKGROUND}

Financial development and economic growth

The positive impact of financial development on economic growth is based on the idea that the services provided by financial intermediaries influence saving and investment decisions (capital accumulation), technological innovation (productivity), and long-run growth. Efficient functioning of the financial markets increases the possibility of choosing productive investments by managing the liquidity risk and diversifying the investor portfolios. Moreover, financial intermediaries can affect economic growth by providing financing to innovative investment opportunities and by managing the risks inherent in these new projects.

Typically, high-return projects require long-term commitments of capital. However, some providers of capital (i.e. small savers) prefer not to relinquish control of their savings for long periods. LEVINE (1991) and Bencivenga and Smith (1991) constructed theoretical models in which financial contracts provided by financial intermediaries mitigate the idiosyncratic liquidity shocks of individuals and facilitate the mobility of savings to be invested in less-liquid but high-return projects. As the risk of premature termination of high-return, long-term investments is reduced, their models show that growth in capital accumulation through successful investments leads to output growth.

Besides dealing with the idiosyncratic liquidity shocks of savers, financial intermediaries ease the risk associated with investing in a single project. Efficient risk diversification by financial intermediaries encourages small savers to increase their loanable funds in the financial system. Levine (1991) and SAINT-PAUL (1992) found that the productivity shocks that discourage risk-averse individuals from investing in a single firm could be diversified away by forming portfolios. Portfolio shifts towards high-return projects increase capital formation and accelerate output growth.

Moreover, in the finance-led growth literature, it is argued that better risk diversification services provided by financial institutions bring increased technological change to the real economy. The papers by GreENWOOD and Jovanovic (1990) and King and LEVINE (1993) showed how the ability to hold a diversified portfolio of innovative projects and the pooling risk of these investments accelerate technological change and economic profit. Because the risk of losing from innovative projects would also be diversified, financial intermediaries invest in growthenhancing innovative activities. 
Imperfect and asymmetric information may inhibit the mobility of capital and cause some differences in regional growth. As long as local investors and financial institutions have superior information about investment opportunities in their region, they have incentives to invest locally, and outside investors may be trapped with inferior investment opportunities, if it is costly to search for alternatives. Hence, the return on capital may vary significantly among regions. Moreover, institutional aspects of financial systems (such as branch-banking regulations, as in the USA), interest rate differentials among regions (due to differences in transaction costs of transferring funds), or risk premiums based on future conditions in the region may impede the free flow of capital among regions. The empirical analysis by GREENWALD et al. (1993) supported the hypothesis of capital market imperfections in the USA, using regional data during the period 1972-1982. FAINI et al. (1993) presented evidence on how informational barriers affected the existence of local financial intermediation in southern Italy. They concluded that southern Italian banks had special informational advantages that allowed them to extract monopoly rents from local firms. Both of these empirical analyses assess the relationship between financial development and regional growth when the institutional banking environment remains fragmented. In particular, they present evidence that companies are more likely to satisfy their financing needs at local banks than at banks with headquarters located in other regions.

The spatial structure of the financial system is also important in analyzing regional development. Financial institutions have become more concentrated in some regional centres since the liberalization of financial regulations during the 1980s (for example, in Britain, GENTLE, 1993, p. 296). In spatially centralized financial systems, financial intermediaries may be biased towards firms in close proximity (Porteous, 1995). As a result, the close regions will have an advantage over the peripheral regions in terms of availability of capital, and these centralized systems may result in uneven regional development. However, decentralized financial systems may provide financing to small- and medium-sized enterprises located in lagging and peripheral regions (KLAGGE and MARTin, 2005).

\section{Institutional environment in Turkey}

Banking sector. The banking sector constitutes a large part of the Turkish financial system. Denizer et al. (2000) stated that the financial system and the banking system are synonymous in Turkey. Banks have dominated every aspect of financial activity in the country and have been responsible for the expansion of the financial system.

The size of the banking sector is relatively small in Turkey compared with developed economies, ${ }^{4}$ although it has been improving. For example, the ratio of bank assets to the nominal GDP was $46.86 \%$ in 1991 and increased to $83.71 \%$ over a decade. Bank deposits were $26.40 \%$ of the GDP in 1991 and $54.94 \%$ in 2000 . Credits provided by commercial banks increased from $20.56 \%$ of the GDP in 1991 to $27.46 \%$ in $2000 .^{5}$

As seen in Table 1 there were 79 banks operating in Turkey, 61 of which were commercial banks and 18 of which were development and investment banks, which are not allowed to collect deposits but may engage in financial leasing services. ${ }^{6}$ Commercial banks are not allowed to trade in goods, real estate or stock markets or to perform financial leasing activities. Four banks were state-owned, and foreigners owned 18 banks. In $2000,34.3 \%$ of the assets of the banking system was controlled by state-owned banks, whereas $49.5 \%$ was owned by private banks. Public banks support a variety of government-subsidized lending programmes, such as to agriculture, small- and medium-sized enterprises, and public foundations in Turkey. The largest bank in Turkey, Ziraat Bank, is state owned. Since the 1980 financial reform, improvements in human capital and information technology in the sector made Turkish banks among the most sophisticated in their region (DENIZER et al., 2000).

With the liberalization programme in the 1980s, the rules and regulations to improve the structural weakness of the banking system had been also constructed. Table 2 presents the chronology of the major regulations in the banking sector and some financial developments in Turkey since the liberalization. The Treasury and the Central Bank were the principal institutions responsible for bank supervision and regulation. However, the lack of effective implementation of these rules and regulations and moral hazard created by extensive government guarantees to deposits resulted in a lax regulatory environment (CELASUN et al., 1999). The programme developed with the IMF to address Turkey's chronic macroeconomic instability problem has also considered the problems in the banking

Table 1. Number of banks and branches in Turkey

\begin{tabular}{|c|c|c|c|c|}
\hline & \multicolumn{2}{|c|}{$\begin{array}{c}\text { Number of } \\
\text { Banks }\end{array}$} & \multicolumn{2}{|c|}{$\begin{array}{c}\text { Number of } \\
\text { Branches }\end{array}$} \\
\hline & 1991 & 2000 & 1991 & 2000 \\
\hline Public banks & 8 & 4 & 3019 & 2834 \\
\hline Private banks & 26 & 28 & 3313 & 3783 \\
\hline Banks in the savings & & & & \\
\hline Deposit Insurance Fund (SDIF) & - & 11 & - & 1073 \\
\hline Foreign banks & 21 & 18 & 113 & 117 \\
\hline Investment and development banks & 10 & 18 & 17 & 30 \\
\hline $\operatorname{Total}^{\dagger}$ & 65 & 79 & 6462 & 7837 \\
\hline
\end{tabular}

Note: ${ }^{\dagger}$ Twenty and 51 bank branches are located abroad in 1991 and 2000 respectively.

Source: Turkish Banking Association. 
Table 2. The chronology of major bank regulations and some financial developments in Turkey

\begin{tabular}{|c|c|}
\hline Date & Events \\
\hline July 1980 & Interest rates were deregulated \\
\hline July 1983 & $\begin{array}{l}\text { The Savings Deposit Insurance Fund (SDIF) at the Central Bank was established; a nominal upper limit for } \\
\text { each saving account was set for deposit insurance }\end{array}$ \\
\hline May 1985 & $\begin{array}{l}\text { The new Bank Act was enacted to solve structural problems of the banking system by providing a legal } \\
\text { basis for prudential regulation and supervision of banking system; banks were required to have a standard } \\
\text { accounting system and to be audited by the independent external auditors; government was authorized to } \\
\text { change the management of banks in trouble; limits were introduced to the extension of credit to a single } \\
\text { customer and the related parties }\end{array}$ \\
\hline December 1985 & $\begin{array}{l}\text { Banks were required to keep specific loan loss provisions regarding to their past unpaid loans and general } \\
\text { provisions for their loan portfolios }\end{array}$ \\
\hline January 1986 & The Istanbul Stock Exchange was opened \\
\hline January1987 & The interest rate restrictions of the corporate bonds by the Central Bank were removed \\
\hline February 1987 & Central Bank started its open market operations \\
\hline January 1987 & Banks were required to submit their independently and externally audited financial statements to the Central Bank \\
\hline October 1987 & $\begin{array}{l}\text { Banks were required to satisfy the capital adequacy ratio determined in line with the Bank for International } \\
\text { Settlements (BIS) guidelines }\end{array}$ \\
\hline August 1989 & Foreign exchange operations and international capital movements were entirely liberalized \\
\hline June 1991 & The secondary market for Treasury bond and bills market was established \\
\hline April 1994 & $\begin{array}{l}\text { The SDIF was reorganized; the partial deposit insurance was converted to full insurance in order to improve } \\
\text { public confidence in the banking sector; Two institutions became responsible from the supervision and regulation } \\
\text { of banks: the Treasury (on-site examination of banks) and the Central Bank (financial positions of banks through } \\
\text { off-site surveillance system) }\end{array}$ \\
\hline June 1999 & $\begin{array}{l}\text { The new banking law was enacted to strengthen the financial structures of banks and the supervision of banks; } \\
\text { An autonomous Banking Regulation and Supervision Agency (BRSA) was required to be established; banks } \\
\text { are required to establish internal control and risk management systems }\end{array}$ \\
\hline September 2000 & The BRSA became fully functional \\
\hline
\end{tabular}

sector. With the 1999 Banking Act, an independent Banking Regulatory and Supervisory Agency (BRSA) was established to supervise and regulate the Turkish banking sector. This agency took over these functions from the Treasury in September 2000.

During the period 1991-2000, the average number of branches per bank did not change significantly, although half of the existing public banks in 1991 were privatized, and 15 banks (including a public bank) failed over this period. There were 7786 domestic bank branches in the sector, as of December 2000. Compared with other banking systems in the world, the number of branches per bank is relatively high in Turkey; for example, in 2000, there were 99 branches per bank in Turkey, but only 24 branches per bank in the EU countries. ${ }^{7}$ Current regulations set no limit on the number of branches for a private bank. Yet state banks must obtain permission from the Ministry of Finance to open a new branch. Private banks are free to open new branches, but if they open more than ten branches within a year, they must have permission from the Treasury.

Regional differences in Turkey. There are significant differences in economic development and banking activities among regions and provinces in Turkey. The provinces are grouped into seven regions according to their geographical locations: Marmara (11 provinces), Aegean (eight provinces), Central Anatolia (13 provinces), Black Sea (17 provinces), South-eastern Anatolia (seven provinces), Eastern Anatolia (15 provinces), and Mediterranean (nine provinces). Fig. 1 shows a map of Turkey with several provinces and regions. The average growth rate of provincial real GDP per capita from 1991-2000 is shown in Fig. 2. The richest region in terms of real GDP is Marmara, with a mean real GDP per capita of 3,554,083 TL; whereas Eastern Anatolia is the poorest region, with a mean GDP per capita of $285617 \mathrm{TL}^{8}$ Moreover, $37 \%$ of Turkey's GDP in 2000 was produced in Marmara (see Table A1 in the Appendix for the share of each region in GDP, population, banking activities and public expenditures). In 2000, 15\% of Turkey's population was living in Istanbul and this province generated $22 \%$ of Turkey's output in that year. In the Marmara region the population grew, particularly in Istanbul at a rate of almost $35 \%$ during the period 1991-2000, whereas the population in Turkey grew only $18 \%$ over the same period. Because of this rapid increase in population, the real per capita GDP grew by only $2.18 \%$ per year on average in Marmara in this period. The Black Sea region had the highest average growth rate of $2.31 \%$, whereas the average growth rate in GDP per capita was lowest in Eastern Anatolia, at $0.80 \%$ (see the Appendix, Table A2, for the mean and median growth rates in these regions for the period 1991-2000). The average provincial per capita income growth rate was highest in Kilis (7.18\%) 


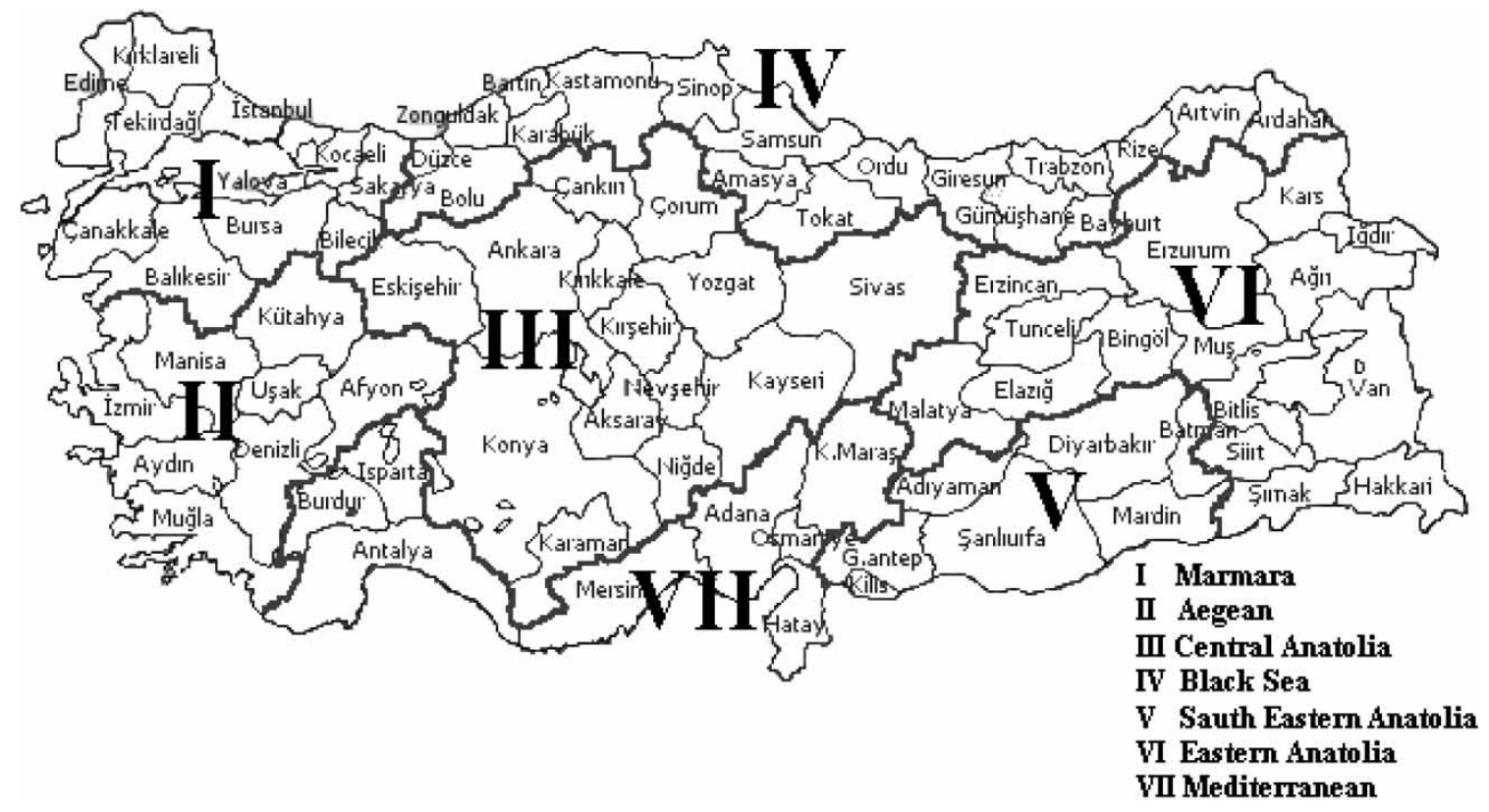

Fig. 1. A map of Turkey with its provinces and regions

and lowest in Osmaniye (-6.58\%); notably, Kilis and Osmaniye are only $159 \mathrm{~km}$ apart. When the growth rates in provincial GDP are compared, the lowest growth rate (-29.71\%) was observed in Artvin in the Black Sea and the highest (32.11\%) in Sirnak in South-eastern Anatolia. Not only do differences in growth rates exist among provinces, but KARADAG et al. (2005) show that productivity also differs among provinces. They found that total factor productivity declined in the highly industrialized provinces and increased in the newly industrialized provinces for the period between 1990 and 1998.
Fig. 3 depicts the average provincial real bank credits per capita during the period 1991-2000. Bank activities were highest on average in the Marmara region. Over $50 \%$ of granted bank credits in 2000 were from this region (Appendix, Table A1). During the analysis period, bank credits per capita in Marmara grew annually at $1.7 \%$ as compared with a $1.2 \%$ annual growth rate in all of Turkey. At the provincial level, the financial centre, Istanbul and the national capital, Ankara, provided most of the credits. It is observed that the highest real credit per capita was 1093780 TL in Ankara, but was only 2940 TL in Sirnak.

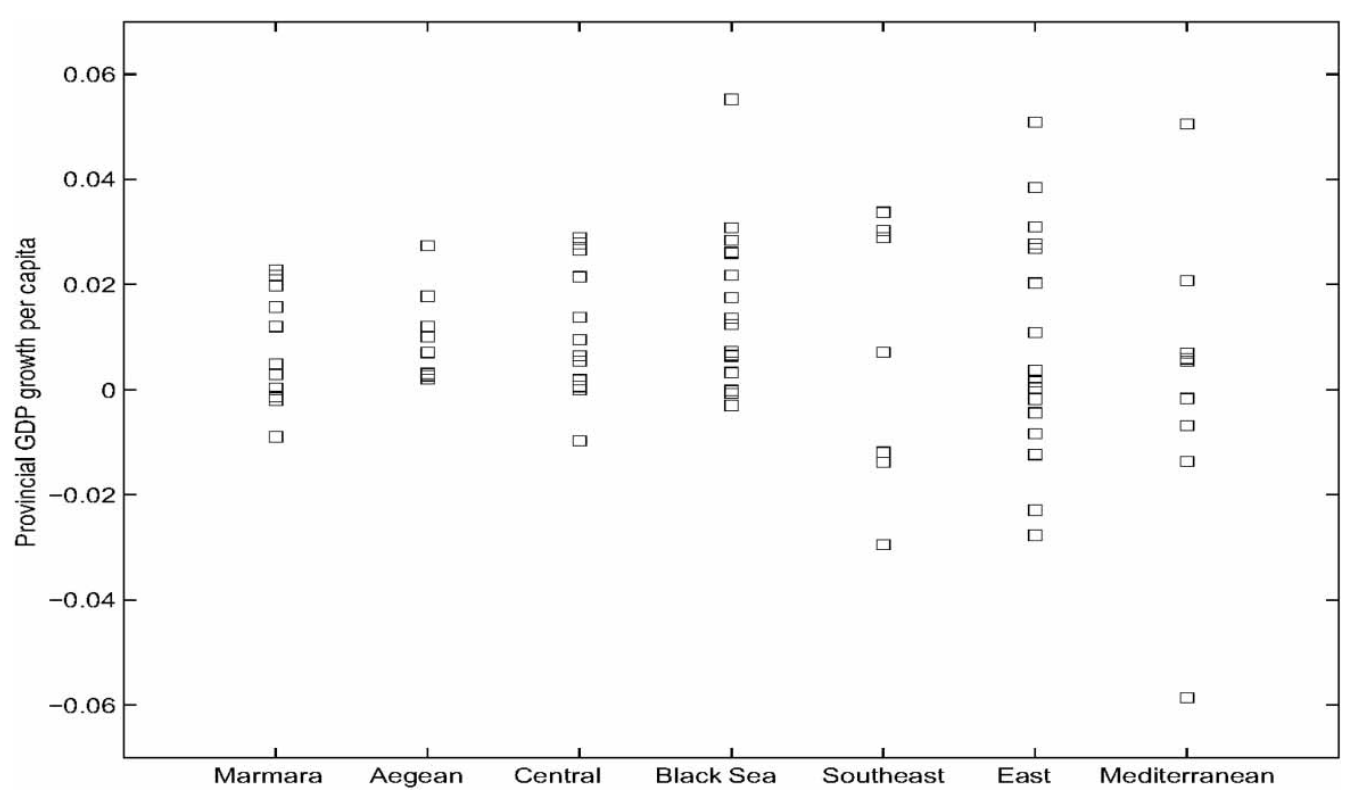

Fig. 2. Average provincial growth of real per capita GDP in provinces located in seven geographical regions in Turkey, 1991-2000 


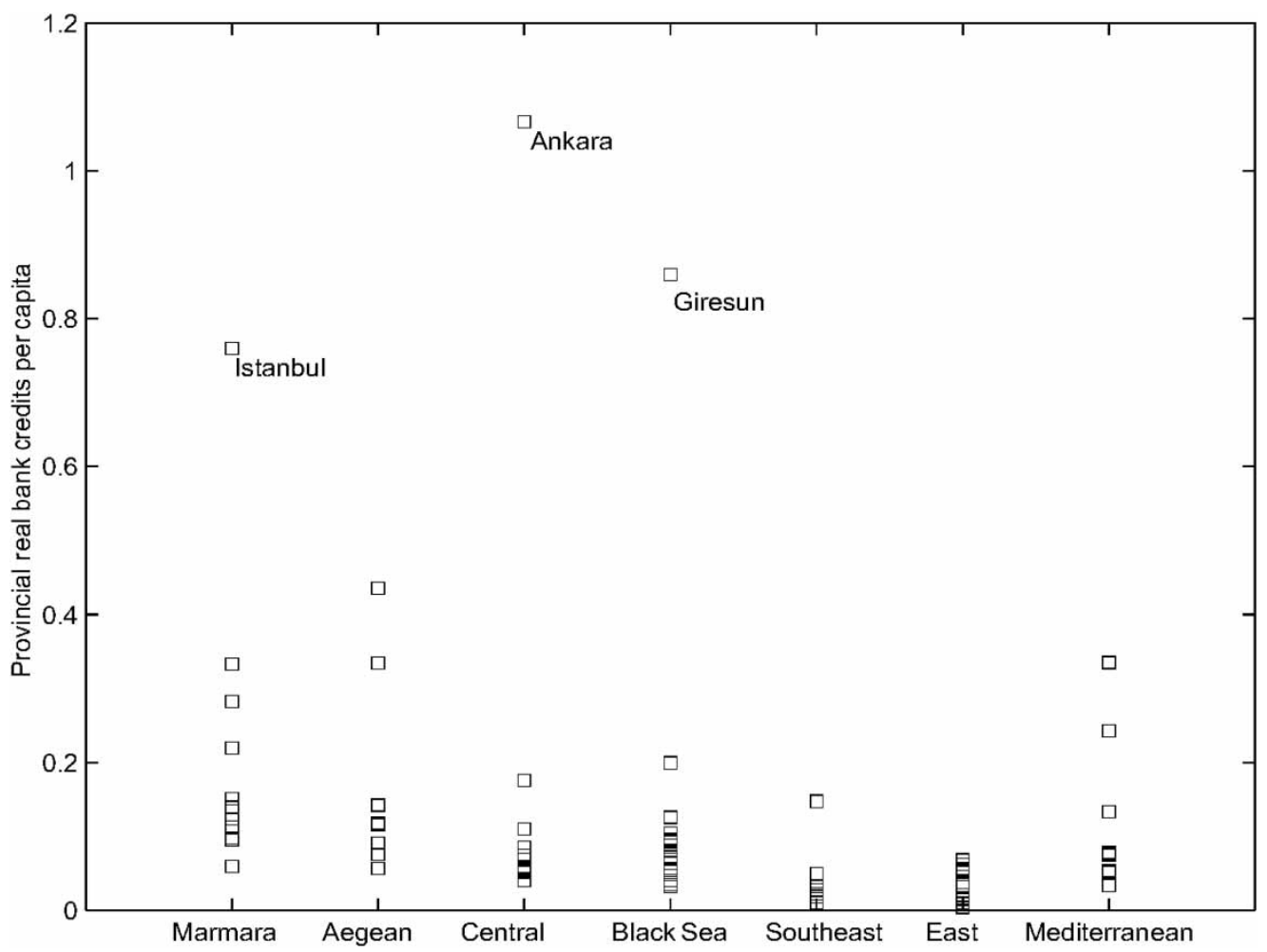

Fig. 3. Average real credits per capita (in million TL) in provinces located in seven geographical regions in Turkey, 1991-2000

Similarly, bank credit to GDP ratio shows high variation among provinces and years: for example, $0.26 \%$ in Sirnak (South-eastern Anatolia) in 1994 and 149.42\% in Giresun (Black Sea) in 1992.

Regions differ in terms of the number of bank branches as well. During the analysis period, it was observed that this number increased consistently in all regions, and that all banks had at least one branch in the Marmara region. Moreover, this region held an average of $36.34 \%$ of all bank branches in Turkey for the period 1991-2000, and its share increased from $33.66 \%$ in 1991 to $39.56 \%$ in 2000 .

\section{EMPIRICAL MODEL}

The basic model

We study the following basic model (Model I) to assess the relationship between financial intermediation and economic growth at the provincial level in Turkey over the period 1991-2000:

$$
\begin{aligned}
\text { Growth }_{i t}= & \alpha_{0}+\alpha_{1} \text { Banking Activity }_{i t} \\
& +\alpha_{2} \text { Control Variables }_{i t}+\varepsilon_{i t}
\end{aligned}
$$

where Growth ${ }_{i t}$ is the growth rate in real GDP per capita in province $i$ at time $t$, calculated by taking the difference in the natural logarithm of GDP per capita. Banking Activity $_{i t}$ is a measure of financial intermediation in province $i$ at time $t$. Control Variables represents a $^{2}$ vector of variables including the public investments, the urbanization rate, the schooling, the inflation rate, and the initial real GDP in province $i$ at time $t$ and a dummy variable indicating the economic crisis years.

In the estimation of the basic model, there are two main econometric problems. One is the provincespecific effects. HSIAO (1986) shows that the omission of individual fixed effects in dynamic panel data will cause the ordinary least squares estimates to be biased and inconsistent. A second problem is the potential endogeneity of independent variables. In order to tackle these issues, we use the dynamic Generalized Method of Moments (GMM) panel estimator proposed by Arellano and Bover (1995) and by Blundell and BOND (1998). This estimator has been widely used in cross-country studies, including CASELli et al. (1996) and LeVine et al. (2000). It controls for the presence of unobserved province-specific effects and for the potential joint endogeneity among explanatory variables by using the previous realization of explanatory variables as an instrumental variable. ${ }^{9}$ With this method, consistent estimates were obtained of the impact of banking activity on the economic growth of Turkish provinces. The consistency of the GMM estimator depends on two conditions. The first is the validity of the assumption that the error term does not exhibit serial correlation as tested with the second-order serial correlation in error terms. The second is the validity of the instrument as tested with the Sargan test. 
In the empirical model, local credit provisions are used to measure local banking activity. There is a large body of evidence indicating that the development of a country's financial sector greatly facilitates its economic growth. In contrast, there is a lack of research on the relationship between the banking sector and economic growth in the context of regional economies. Financial intermediaries increase the availability of local funds by providing liquid instruments to savers that provide higher returns than result from holding their assets out of financial system (a common saving behaviour, especially in rural areas, is to keep gold or cash under a mattress) and by reducing transaction costs. In particular, in a regionally segmented banking system, banks are expected to turn these local funds into productive investment opportunities that will increase local output. However, in a centrally concentrated banking system, intermediation of local savings through local branches creates a pool of funds at the headquarters. Thus, regional credits could be satisfied from this pool in a spatially centralized banking system without considering the regional deposit bases, as emphasized in several studies. For example, Dow and RodriguezFUENTES (1997) state that 'regions with a branch system face a horizontal supply of funds because regional bank branches are able to lend beyond their regional-deposit base'. Hence, we concentrate on the asset side of banking activities and study the impact of local credits on local per capita output growth. However, it can be argued that the level of credits may not be important for the local development if credits are very small relative to the size of the local economy. Therefore, in addition to the local credits per capita, the loan provisions-to-GDP ratio is used to measure banking activity.

As specified in the basic model, several provincial characteristics have to be controlled for when analyzing the impact of banking activity on local economic development. Inflation is one of the control variables. Provincial inflation rate - the change in the provincial GDP deflator - is used to measure economic stability in a province. If inflation is high in the area, real growth will be low for several reasons. For example, the interest rates on credits will be higher, and it may be difficult to repay the obligations. Thus, the demand for loans will decline because of the high cost of financing. ${ }^{10}$ In addition, the expected return on investments is required to be high because of high inflation. This will limit attractive investment opportunities (BARRO, 1997).

The public sector investments, the urbanization rate and the schooling rate of a province are the other control variables included in the model. Public sector investments are measured by the logarithm of the public expenditures in the province or the public expenditure-to-GDP ratio, depending on the measure of banking activity used in the model. Urbanization rate indicates the percentage of population living in urban areas. Black and Henderson (1999) argue that there is very high correlation between urbanization and economic growth especially in developing countries because transformation of an economy to an industrial-service based economy with urbanization will contribute to economic growth by promoting information spillovers amongst producers, and more the efficient functioning of goods, labor and financial markets. Schooling rate is used as a proxy to measure the impact of human capital at the regional level and is expected to contribute growth in the region (BARRO and LEE, 1996). This variable is defined as the number of high-school teachers per high-school student in the province. The traditional measure of schooling, i.e. the number of years of schooling is not used because of its unavailability at the provincial level.

The initial level of wealth in each province is included in the model to control for convergence, as suggested by LEVINE et al. (2000). Finally, because the level of national and regional outputs would decline during the crisis periods, a dummy variable, which takes a value of 1 for the crisis years: 1991, 1994 and 1999, is also incorporated into the model. Although Turkey did not face economic crisis in 1991, the first Iraq war adversely affected the Turkish economy. Turkey had major banking and liquidity crises in 1994 and 1999. The Turkish Lira was devalued against the US dollar by $62.23 \%$ in 1994 . In addition, the crisis in 1999 resulted in the failure of six private banks.

\section{Model with spatial effects}

In this paper, we argue that physical distance from the bank headquarters is important for the credit provision decisions of local banks. Porteous (1995) finds that when the cost of monitoring increases with the distance between the bank and the borrowers, spatial credit rationing results. Because the institutional structure of banks in Turkey is centralized, credit approvals, especially large-denominated ones have to be obtained from the headquarters. For the provinces that are closer to the headquarters, the process of granting credit will be fast, and risks due to agency problems will be managed better. For example, loan officers at the headquarters are likely to know the investment opportunities in the nearby regions, so they would deal with adverse selection problems better (BERGER et al., 2005). Furthermore, if all funds are distributed from the headquarters, the availability of loanable funds might be higher around headquarters than in other parts of the country (Porteous, 1995, 1999). As seen in the appendix, the Marmara region where Istanbul is located holds over half of the credits granted in Turkey, whereas the regions that are further away from Istanbul, for example, the Eastern and South-eastern regions, account for less than $2 \%$ of total credits. Because the headquarters of all private banks operating in Turkey are located in Istanbul, we 
define a variable, Distance, as the physical distance between Istanbul and a province $i$ where the local bank operates. It is assumed that the distance per se does not affect the per capita output growth in the province, but it affects the impact of banking activity on local development due to geographical concentration of the financial activities in Turkey. Therefore, the interaction variable between banking activity and physical distance is included in the basic model to examine whether the centralized structure of banks in Turkey affects the role of banks in the growth of local per capita output (Model II):

$$
\begin{aligned}
\text { Growth }_{i t}= & \alpha_{0}+\alpha_{1} \text { Banking Activity }_{i t} \\
& +\alpha_{2} \text { Distance }_{i} \times \text { Banking Activity }_{i t} \\
& +\alpha_{3} \text { Control Variables }_{i t}+\varepsilon_{i t}
\end{aligned}
$$

It is known in the literature that small firms rely on banks as a source of external finance, because of the lack of a publicly organized secondary market for their equities and debts (Pollard, 2003; Klagge and Martin, 2005). In Turkey, most of the large firms are located in Marmara, and as we move out of this region, the number of large businesses declines. For example, 293 out of the 500 largest firms in Turkey are located in the Marmara region (ISTANBUL Chamber of Industry, 2004). Large firms located close to Istanbul are better known nationally and able to raise equity from the stock market. Hence, the firms located far from Istanbul are argued to rely on banks for financing, and it is expected that the positive impact of banking activity on per capita income growth increases with physical distance from Istanbul.

Alternatively, the financial conditions of many loan customers, especially small businesses, are not easy to assess or monitor. Hence, loan decisions will depend on soft information, such as opinions, ideas, rumours, economic projections, statements of the management's future plans and market commentary, which the local bank branch managers would know. However, the quality of this soft information depends on the efforts of local officers in the local banks. It can be argued that increasing banking activities in the distant provinces leads to unproductive investments, because local banking officers or managers may be less inclined to collect information for loan requests and to monitor centrally granted loans. Knowing excessive information and agency costs inherent in the local loans, decision makers at the head offices might try to lower the content of the soft information in the local loan requests. It would be less risky for the banks to use codified knowledge, i.e. that which is explicit and standardized over these long distances. MORGAN (2004) argues that the significance of physical proximity depends on the complexity of the project, i.e. the degree of 'tacitness' involved. Because of the increasing tacitness in the loan transactions of distant regions, we expect that loans granted in the farther provinces may contribute less to the local development. Moreover, these loans may be used to finance working capital instead of investments. Yet, some banks, especially the large ones are prudent in lending, even to distant provinces. Considering all of these conflicting effects, how the relationship between banking activities and local prosperity will change with the distance from the headquarters is hard to predict.

It can be argued that physical distance is not important, because technology increases the speed of information flow between the headquarters and the local branches. If there is increased communication between the headquarters and the bank branches in a province, both hard and soft information will flow fast and accurately. Therefore, we define another measure of distance, Distance per Branch, by dividing the physical distance between a province and Istanbul by the number of branches in that province. It is assumed that if there are many branches in a province, there will be much interaction between the province and the headquarters. Thus, physical distance is adjusted to account for the possible impact of increasing the flow of information about the potentials of the province.

In addition to these two measures, a dummy variable, Eastern, is created that takes a value of 1 for the provinces located to the east of Ankara and we test the hypothesis that the relation between banking activity and local growth differs in the eastern provinces in Turkey. Although there is no formal division of the country into two parts, usually provinces located to the east of the national capital, Ankara, are considered to be less developed and less westernized. Like the other distance measures, no clear-cut sign is hypothesized on this interaction variable because of the unavailability of other sources of financing and the increase in asymmetric information.

Data and sample

A panel dataset is constructed by employing annual data on provincial output and indicators of financial intermediation for the period 1991-2000. The beginning of the sample period is determined by the availability of data at the provincial level. The sample period ends in 2000, because the banking environment became more regulated in 2001 with the establishment of the Banking Supervision and Regulation Agency. The Agency asked the banks to have internal control and risk management systems. This new regulation might change the responsibility of the units at the headquarters in granting credits.

There were 67 provinces in Turkey at the beginning of the sample period, and 14 new provinces were established during the sample period. Because these provinces were formed from the districts of the existing provinces, the GDP level will decline artificially in old provinces from which new provinces were constructed. Therefore, these old provinces were not included in the sample in the year when new provinces were formed. ${ }^{11}$ Hence, data are unbalanced with 676 observations. All of the data about the banking activities are obtained from the Turkish Banking Association. The other 
variables are taken from the State Institute of Statistics. Table 3 shows the descriptive statistics of the variables.

The descriptive statistics indicate the differences among provinces in terms of regional development, as explained earlier. Although the average GDP growth rate per capita in the provinces is $1.67 \%$, it varies between $-29.71 \%$ and $32.11 \%$. Similarly, banking activity varies among provinces.

Provinces are different in terms of control variables as well. The inflation rate is very high. The average provincial inflation rate was $54.50 \%$. Over half of the population lives in urban areas. Although there was one highschool teacher for 14 students on average (or seven teachers per 100 high-school students), the schooling measure varies among provinces from one teacher per 50 students to one teacher per five students.

\section{EMPIRICAL RESULTS}

We first analyze the impact of local bank loans per capita (measured in natural logarithms) on the economic prosperity of Turkish provinces. The results of the dynamic GMM estimations with this measure of banking activity

Table 3. Descriptive statistics of variables

\begin{tabular}{|c|c|c|c|c|}
\hline Variable & Mean & $\mathrm{SD}$ & Minimum & Maximum \\
\hline \multicolumn{5}{|l|}{ Growth variables } \\
\hline $\begin{array}{l}\text { GDP growth } \\
\text { rate }(\%)\end{array}$ & 2.57 & 7.42 & -62.75 & 35.56 \\
\hline $\begin{array}{l}\text { GDP per capita } \\
\text { growth rate }(\%)\end{array}$ & 1.67 & 7.84 & -29.71 & 32.11 \\
\hline \multicolumn{5}{|l|}{ Banking variables } \\
\hline $\begin{array}{l}\text { Bank } \\
\text { credits/GDP (\%) }\end{array}$ & 8.53 & 13.06 & 0.26 & 149.42 \\
\hline Credits per capita ${ }^{\dagger}$ & 120.73 & 189.4 & 0.84 & $1,716.44$ \\
\hline $\begin{array}{l}\text { Credits per } \\
\text { branch (TL) }\end{array}$ & 1152.12 & 1425.53 & 27.88 & 13538.91 \\
\hline \multicolumn{5}{|l|}{ Distance measures } \\
\hline $\begin{array}{l}\text { Distance from } \\
\text { Istanbul }(\times 1000 \mathrm{~km})\end{array}$ & 0.83 & 0.44 & 0.00 & 1.82 \\
\hline $\begin{array}{l}\text { Distance from } \\
\text { Istanbul per } \\
\text { branch }(\mathrm{km})\end{array}$ & 36.29 & 47.30 & 0.00 & 296.25 \\
\hline $\begin{array}{l}\text { Eastern dummy } \\
\text { variable }\end{array}$ & 0.66 & 0.47 & 0.00 & 1.00 \\
\hline \multicolumn{5}{|l|}{ Control variables } \\
\hline $\begin{array}{l}\text { Public expenditure/ } \\
\text { GDP (\%) }\end{array}$ & 2.45 & 4.16 & 0.09 & 42.19 \\
\hline Inflation rate $(\%)$ & 54.5 & 11.38 & 6.57 & 122.34 \\
\hline $\begin{array}{l}\text { Urbanization } \\
\text { ratio }(\%)\end{array}$ & 52.53 & 13.03 & 20.18 & 92.71 \\
\hline Schooling $^{\dagger \dagger}$ & 0.07 & 0.02 & 0.02 & 0.21 \\
\hline
\end{tabular}

Notes: ${ }^{\dagger}$ In million TL.

${ }^{+{ }^{+}}$The ratio of the number of high-school teachers per highschool student. Bank credits are measured at the end of the year, whereas the GDP is calculated over the year. In order to eliminate this measurement error, the average credit values are calculated using their beginning and ending balances in each year. are presented in Table 4. Our results support the previous findings in cross-country studies that provincial bank credits have a positive impact on the local per capita growth, controlling for the other regional and macroeconomic factors. ${ }^{12}$ However, when the interaction variable between distance and bank credits is included in the model, the direct impact of credits on local growth declines and becomes insignificant in general, suggesting that spatial distribution of local loans is important in analyzing the local per capita growth rates at the provincial level.

The impact of the spatial structure of the banking system in Turkey on the local development is examined with three distance measures. When the physical distance between Istanbul and the province is used (Model IIa), we find a negative but insignificant coefficient on the absolute level of bank loans and a positive and significant coefficient on the interaction variable between physical distance and the amount of local bank loans, i.e. the farther the province is from Istanbul (headquarters), the higher is the positive impact of credits on local growth. These results suggest that although bank loans in the provinces close to the financial centre do not significantly affect the well-being of the residents, the bank loans granted in the peripheral provinces contribute greatly to per capita income. This finding can be explained by the segmentation of financial markets, especially limited access to capital markets from remote regions. Because most of the small firms are located outside of Marmara region, these firms may be dependent on bank loans as a source of financing their investments.

The second distance measure is calculated by dividing the physical distance from Istanbul by the number of branches in the province. It is assumed that if there are more branches in the province, there will be more communication between the province and those at the decision centre of banks. As seen in the third column of Table 4 (Model IIb), although the provision of local loans had a positive and significant effect on the local per capita income growth rate, the coefficient on the interaction variable is not found to be significant. More precisely, we can say that the physical distance of the province adjusted with the provincial bank concentration did not change the impact of banking activities significantly, suggesting that geographical location of the provinces is crucial to estimate the impact of banking activities on local development.

As seen in the fourth column of Table 4 (Model IIc), the positive effect of loans on local growth is higher in the east than in the west, although credits per se did not significantly increase local growth. This finding indicates that additional loan provisions to the eastern provinces have a greater impact on the growth rate, than provisions to those in the west. The coefficient on this variable also supports our interpretation that bank loans may be the only alternative for the small firms located in the eastern provinces of Turkey.

The role of bank credits might change when we consider the size of the credits relative to the size of the local 
Table 4. GMM results with bank credits per capita as a measure of banking activity

\begin{tabular}{|c|c|c|c|c|}
\hline & I & IIa & $\mathrm{IIb}$ & IIc \\
\hline Intercept & $-0.0023(0.3669)$ & $-0.0021(0.4125)$ & $-0.0023(0.3636)$ & $-0.0022(0.3830)$ \\
\hline Log (credits per capita) & $0.0439(0.0086)$ & $-0.0036(0.8946)$ & $0.0370(0.0484)$ & $0.0063(0.7599)$ \\
\hline Initial $\log (\mathrm{GDP})$ & $0.8512(0.0001)$ & $0.8103(0.0001)$ & $0.8415(0.0001)$ & $0.8029(0.0001)$ \\
\hline Urbanization & $0.1849(0.1070)$ & $0.2700(0.0196)$ & $0.2021(0.0923)$ & $0.2460(0.0253)$ \\
\hline Schooling & $0.3229(0.2017)$ & $0.1853(0.4670)$ & $0.3039(0.2332)$ & $0.1875(0.4710)$ \\
\hline Log (public expenditures) & $0.0160(0.0078)$ & $0.0156(0.0114)$ & $0.0156(0.0095)$ & $0.0188(0.0012)$ \\
\hline Inflation & $-0.1117(0.0010)$ & $-0.1177(0.0005)$ & $-0.1124(0.0009)$ & $-0.1051(0.0016)$ \\
\hline Crisis dummy & $-0.0417(0.0001)$ & $-0.0427(0.0001)$ & $-0.0419(0.0001)$ & $-0.0413(0.0001)$ \\
\hline \multicolumn{5}{|c|}{ Interaction variables: Distance } \\
\hline Distance & & $0.0346(0.0184)$ & & \\
\hline Distance per branch & & & $0.0799(0.3715)$ & \\
\hline Eastern dummy variable & & & & $0.0432(0.0019)$ \\
\hline Adjusted $R^{2}$ & 0.8604 & 0.8630 & 0.8606 & 0.8653 \\
\hline$N$ & 676 & 676 & 676 & 676 \\
\hline$\rho$ & -0.1116 & -0.1213 & -0.1129 & -0.1195 \\
\hline$\chi^{2}$ (Sargan test) & 0.00 & 0.00 & 0.00 & 0.00 \\
\hline
\end{tabular}

Notes: $p$-values are in parentheses. $\rho$ represents second-order autocorrelation in error terms. It is used to test the null hypothesis that the errors in the first difference regression exhibit no second order serial correlation. The Sargan test is used to test the hypothesis that the instruments used are not correlated with the residuals.

economy. In Table 5, we present the results of the model, where banking activity is measured relative to the GDP of a province. It is found that the availability of local credits relative to the GDP of a province has no significant effect on the per capita local well-being. However, the impact of the banking activities is found to be positive and significant when its interaction with several measures of distance is included in the model. When the spatial structure of the banking system is controlled, an increase in bank credits with respect to a given local GDP is found to improve the local per capita output significantly. The change in the coefficient on the credit-to-GDP ratio can be explained by the negative impact of banking activity on local growth in the provinces far from Istanbul. The first model does not take into account the spatial distribution of loans. Moreover, there is a significant and negative correlation between distance measures and this ratio (the correlation is $-0.14,-0.18$ and -0.10 for the physical distance, the physical distance adjusted with the number of branches, and the eastern dummy variable, respectively).

Table 5. GMM results where bank credits-to-provincial GDP ratio is used as a measure of banking activity

\begin{tabular}{|c|c|c|c|c|}
\hline & I & IIa & IIb & IIc \\
\hline Intercept & $-0.0024(0.3539)$ & $-0.0023(0.3698)$ & $-0.0017(0.5180)$ & $-0.0024(0.3595)$ \\
\hline Credits/GDP & $-0.0972(0.3503)$ & $0.3451(0.0456)$ & $0.2990(0.0246)$ & $0.1851(0.0763)$ \\
\hline Initial log (GDP) & $0.9117(0.0001)$ & $0.8975(0.0001)$ & $0.8692(0.0001)$ & $0.9005(0.0001)$ \\
\hline Urbanization & $0.2347(0.0488)$ & $0.1833(0.1328)$ & $0.1472(0.2039)$ & $0.1802(0.1384)$ \\
\hline Schooling & $0.3348(0.1794)$ & $0.2937(0.2344)$ & $0.2499(0.3097)$ & $0.2899(0.2455)$ \\
\hline Public expenditures/GDP & $-0.0656(0.6728)$ & $-0.0566(0.7145)$ & $-0.0135(0.9261)$ & $-0.0591(0.7027)$ \\
\hline Inflation & $-0.1780(0.0001)$ & $-0.1801(0.0001)$ & $-0.1888(0.0001)$ & $-0.1779(0.0001)$ \\
\hline Crisis dummy & $-0.0504(0.0001)$ & $-0.0495(0.0001)$ & $-0.0498(0.0001)$ & $-0.0493(0.0001)$ \\
\hline \multicolumn{5}{|c|}{ Interaction variables: Distance Measure $\times($ Credit $/ G D P)$} \\
\hline Distance & & $-0.5080(0.0051)$ & & \\
\hline Distance per branch & & & $-21.9883(0.0001)$ & \\
\hline Eastern dummy variable & & & & $-0.3170(0.0020)$ \\
\hline Adjusted $R^{2}$ & 0.8559 & 0.8575 & 0.8628 & 0.8571 \\
\hline$N$ & 676 & 676 & 676 & 676 \\
\hline$\rho$ & -0.1149 & -0.1086 & -0.0893 & -0.1125 \\
\hline$\chi^{2}$ (Sargan test) & 0.00 & 0.00 & 0.00 & 0.00 \\
\hline
\end{tabular}

Notes: $p$-values are in parentheses. $\rho$ represents second-order autocorrelation in error terms. It is used to test the null hypothesis that the errors in the first difference regression exhibit no second order serial correlation. The Sargan test is used to test the hypothesis that the instruments used are not correlated with the residuals. 
Hence, the ratio of the provision of bank credits to the size of the local economy is less for the provinces far from Istanbul.

Our estimations indicate that the farther the province is from Istanbul, the less is the impact of banking activities on local growth. Some distant provinces may even be worse off. This finding is consistent regardless of the distance measure included in the model. The other two distance measures also yield the same results, indicating that the improvement of local bank credits to the provinces significantly contributes to the per capita local growth, but that the impact of the banking activities significantly declines when a province is located far from the financial centre. The negative coefficient on the interaction variable can be explained in several ways. Because information and agency costs may exacerbate in the distant provinces, the approved loans to those provinces may not be used to finance investments with positive expected returns or they might only be used as working capital. Thus, these loans will not contribute to the prosperity of the local economy. Moreover, our measure of banking activity includes all types of credits granted by state and private banks. State banks have been used as agents to distribute credits to certain favoured groups. ${ }^{13}$ Some of these credits are used to finance public enterprises and municipalities. Two major state banks - Ziraat Bank and Halk Bank - were established to provide subsidized loans to farmers and small firms in less developed regions. For example, Marmara region received more than half of total loans granted in Turkey, but only $9 \%$ of agricultural loans were given in this region in 2000, whereas the Eastern and South-eastern regions received $26 \%$ of the agricultural loans, although they received only $2.4 \%$ of the total loans granted. These credit allocations may suggest that bank funds were mainly used not to finance productive investments in distant provinces.

In both sets of regression models summarized in Tables 4 and 5, we control certain regional and macroeconomic factors, which are hypothesized to affect the local per capita output growth rates in Turkey. In the first set of regression analysis, we observe that initially low-income provinces experience a significantly high growth rate that generally is characteristic of developing areas. Moreover, we find that the urbanization of the provinces and the increasing public expenditures to them improved the local prosperities significantly, supporting the mainstream theory on growth, which predicts a positive effect (BARRO, 1997). However, our human capital measure, schooling, had a positive but insignificant impact on the local per capita output growth. Furthermore, both persistent increases in local prices and economic crises affected regional development adversely. In the second set of regressions, where banking activity is measured relative to the GDP in a province, the sign and the significance of the control variables are similar. However, when the impact of public expenditures is examined relative to
GDP in the province, it is not found to affect the local well-being significantly.

\section{CONCLUSION}

This paper reports the results of an empirical study that examines whether local banking activities influence local output growth in Turkey during the period 1991-2000. Although there is no legal restriction against regional banking, the institutional structure of the banking sector is spatially concentrated in Turkey. In this setting, it is argued that the distance between headquarters and the local branches is an important factor to understand the effect of financial intermediation on the economic growth of the provinces. In line with the cross-country analysis, we observe a positive and significant relationship between local loan provisions and per capita local output growth. However, the impact of bank loans on the well-being of the local economy changed significantly with the consideration of the geographical location of the provinces. More precisely, we find that, in absolute terms, increasing loan provisions to distant provinces contributes further to the per capita income of those provinces. A positive relationship is observed between the provision of bank loans to the distant provinces and local growth rates. This finding can be explained by the fact that provinces closer to the financial centre are more developed, economically and socially than those far away. However, when we adjust the impact of bank loans to the size of the local economy (provincial GDP), increases in banking activities are found to lower the output per capita as the distance from the headquarters increases, suggesting that these loans are used to finance unprofitable and unproductive projects.

The findings support the recent arguments in the literature about the spatial dimension of financial systems. For example, similar to Porteous (1995), the regions close to the financial centre are found to have advantage over peripheral regions in terms of availability of bank credits and local economic growth. Moreover, distant provinces where small-sized borrowers reside also benefit from bank funds because of unavailability of other sources of capital, supporting KLAGgE and MARTin (2005).

The results of this study have several policy implications. First, in order to improve the well-being of residents in distant regions, the regulators should require banks to change their organizational structure from the centralized system. For example, the establishment of regional headquarters may lower information and agency costs in granting credits to finance projects of small firms and banks might help local development. The second policy implication would be to increase incentives for the development of the microfinance sector. The credit demand of the unbanked borrowers, i.e. small and opaque borrowers, can be satisfied through microfinance institutions. Moreover, these 
borrowers may have a record of loan transactions to apply for obtaining bank loans in the future. Otherwise, the empirical results of this study suggest that poor utilization of financial services never leads to economic development in those regions. Third, the Banking Supervision and Regulatory Agency may ask banks' headquarters to delegate some responsibility to local managers in granting credits in order to facilitate local development.

For further study, enriching the measurement of distance would improve our understanding of the effect of organizational structure in the banking sector on local per capita output. For example, social distance - the intimacy between the managers in the head office and local branch managers - may influence judgements on the quality of soft information collected at the local branch. Thus, the allocation of loans may depend on social closeness instead of physical proximity. Moreover, the decision criteria for the approval of credits are generally different for public and private banks. Typically, private banks provide credits based on the risk structure of the projects; however, public banks may be asked to allocate credit to certain sectors below their cost and without considering the profitability of the projects. Hence, credits from different types of banks may affect

\section{APPENDIX}

Table A1. Shares of regions in banking activity, GDP, population and public expenditures in Turkey (\%)

\begin{tabular}{|c|c|c|c|c|c|c|c|}
\hline & Marmara & Aegean & Central Anatolia & Black Sea & South-eastern Anatolia & Eastern Anatolia & Mediterranean \\
\hline \multicolumn{8}{|l|}{ Between 1991-2000 } \\
\hline Bank branches & 36.34 & 17.25 & 16.60 & 11.15 & 3.71 & 4.91 & 10.04 \\
\hline Credits & 46.00 & 11.20 & 25.81 & 5.88 & 1.59 & 1.24 & 8.27 \\
\hline Deposits & 47.85 & 11.56 & 24.93 & 5.61 & 1.53 & 1.86 & 6.66 \\
\hline GDP & 36.63 & 15.50 & 15.98 & 9.60 & 5.39 & 4.62 & 12.27 \\
\hline Population & 25.05 & 13.48 & 16.53 & 13.05 & 8.93 & 10.12 & 12.84 \\
\hline Public expenditure & 26.33 & 14.65 & 19.06 & 10.47 & 9.01 & 10.37 & 10.11 \\
\hline \multicolumn{8}{|l|}{ In 1991} \\
\hline Bank branches & 33.66 & 17.61 & 17.52 & 12.69 & 3.62 & 5.28 & 9.61 \\
\hline Credits & 39.96 & 11.18 & 27.66 & 7.34 & 1.55 & 1.49 & 10.82 \\
\hline Deposits & 42.82 & 12.19 & 27.78 & 6.60 & 1.75 & 2.19 & 6.67 \\
\hline GDP & 36.65 & 15.44 & 16.27 & 9.63 & 5.67 & 4.73 & 11.60 \\
\hline Population & 23.77 & 13.47 & 16.92 & 14.17 & 8.73 & 10.45 & 12.49 \\
\hline Public expenditure & 22.22 & 20.88 & 16.55 & 9.58 & 12.41 & 9.48 & 8.90 \\
\hline \multicolumn{8}{|l|}{ In 2000} \\
\hline Bank branches & 39.56 & 16.49 & 15.94 & 9.62 & 3.7 & 4.55 & 10.15 \\
\hline Credits & 51.20 & 10.02 & 21.16 & 7.24 & 1.81 & 1.61 & 6.95 \\
\hline Deposits & 52.26 & 9.95 & 24.47 & 4.24 & 1.19 & 1.37 & 6.53 \\
\hline GDP & 37.04 & 15.28 & 16.30 & 9.46 & 5.09 & 4.64 & 12.19 \\
\hline Population & 25.51 & 13.21 & 16.58 & 12.50 & 8.94 & 10.25 & 13.02 \\
\hline Public expenditure & 27.00 & 12.36 & 11.21 & 17.19 & 8.76 & 8.24 & 15.25 \\
\hline
\end{tabular}

Source: Authors' calculation from the data obtained from Turkish Banking Association (http://www.tbb.org.tr) and State Planning Organization (http://www.dpt.gov.tr/bgyu/bgyu.html).

Table A2. Yearly credits per capita (in terms of 1987 prices) and yearly growth rate of real GDP per capita (in terms of 1987 prices) in provinces, classified by regions, 1991-2000

\begin{tabular}{|c|c|c|c|c|}
\hline \multirow[b]{2}{*}{ Regions } & \multicolumn{2}{|c|}{$\begin{array}{c}\text { Credits per capita (1987 prices, } \\
\text { in million TL) }\end{array}$} & \multicolumn{2}{|c|}{$\begin{array}{c}\text { Growth rate of real GDP per capita } \\
\text { (in percentage) }\end{array}$} \\
\hline & Mean & Median & Mean & Median \\
\hline Marmara & 215.4 & 134.7 & 2.18 & 2.61 \\
\hline Aegean & 175.1 & 116.3 & 2.10 & 3.27 \\
\hline Central Anatolia & 161.0 & 63.8 & 2.11 & 1.92 \\
\hline Black Sea & 120.6 & 69.7 & 2.31 & 2.56 \\
\hline South-eastern Anatolia & 43.8 & 28.6 & 0.83 & 0.40 \\
\hline Eastern Anatolia & 29.8 & 21.3 & 0.80 & 0.51 \\
\hline Mediterranean & 128.8 & 55.8 & 0.98 & 1.03 \\
\hline
\end{tabular}

Note: *Monetary values are in terms of 1987 prices $(\$ 1=1021 \mathrm{TL} ; \mathcal{E} 1=1897 \mathrm{TL})$.

Source: Authors' calculation from the data obtained from State Planning Organization (http://www.dpt.gov.tr/bgyu/bgyu.html). 
the local well-being in a different way. Furthermore, commercial banks are not the only institutions that grant credits. The activities of other financial institutions such as finance companies have been increasing, especially in rural areas. People who are credit-rationed by banks can receive credits to finance their projects from these institutions. For example, pawnbrokers may provide credit, especially in areas where there is an excess demand. When the data are available, the impact of legal and non-legal financial intermediaries on local growth might be another avenue for further research.

Finally, we suggest that empirical modelling of the paper can be used to study the impact of loan provisions by foreign banks on local economies. With a similar organizational structure to that of Turkey, branches of foreign-based banks will experience informational and agency costs in geographically different markets. Although these costs will be exacerbated with cultural differences, advanced informational technology and the risk management practices of these banks might enhance the economic growth of host countries.

\section{NOTES}

1. The direction of the causality between financial intermediation and growth has been debated for a long time. Taking one side of this argument, SCHUMPETER (1962) claimed that financial systems are important for growth and that the economies with more efficient financial systems grow faster. Alternatively, RoBINSON (1952) stated that economies with good growth prospects need financial institutions for the provision of funds. Hence, first, the economy grows. Then, financial institutions develop. For a detailed survey, see Levine (1997).

2. This is called the Cyert, March and Simon model of decision making. It is the organizational analogue of the bounded rationality approach at the individual level.

3. The Turkish banking system is highly centralized, similar to Australia, Canada, and Chile (Porteous, 1995), and Hungary (GAL, 2005).

4. For example, in 2000, bank deposits were 179\%, 128\% and $69 \%$ of the GDP in the UK, Germany and France, respectively. The bank credits-to-GDP ratios were higher than their deposit-to-GDP ratios; 185\%, 167\% and $93 \%$ in these countries. Moreover, bank assets were 3.82, 3.49, and 2.52 times higher than their GDPs in the UK, Germany and France in 2000. These figures are calculated using the statistics obtained from the European Banking Federation (2000).

5. These figures are calculated using the data from the World Bank World Development Indicators (GDP) and the Turkish Banking Association (total assets, deposits and credits).
6. In addition to deposit banks, there are five special finance houses (SFHs) that are allowed to collect funds and to grant credit in Turkey. Unlike deposit banks, they do not provide interest to the depositors as a return, but they distribute positive or negative returns that they get from the investment of these funds. SFHs operate as Islamic banks in Turkey. In 1995, their shares in assets, deposits and credits in the banking sector were only $1.87 \%, 2.43 \%$ and $3.46 \%$ respectively. However, their shares have increased slightly: $2.1 \%, 2.6 \%$ and $4.8 \%$ in 2000. Because of the unavailability of provincial data about their activities, their impact on local development is not analyzed in the current study.

7. Source: European Banking Federation website, General Statistics on the European Financial Sector as of 31 December 2000 (http://www.fbe.be).

8. The mean GDP per capita was $\$ 3490$ in the Marmara region and $\$ 280.5$ in the Eastern Anatolia region during the period 1991-2000.

9. This method assumes that explanatory variables are weakly endogenous, i.e. they can be affected from the past and current realization of the growth rate, but future unanticipated shocks to growth do not affect the current banking activity. For a detailed explanation of this estimation, see for example, Levine et al. (2000).

10. Unfortunately, the data on interest rates are not available. We assume that interest rates were different across regions and banks offer different interest rates depending on the riskiness of borrowers. If there is no difference in regional interest rates, those who borrow from the regions with high inflation rates will experience lower real interest rates. We would like to thank the anonymous referee for pointing out this issue.

11. For example, Igdir and Ardahan were districts of Kars and became provinces in 1993. The GDP figure for Kars in 1992 included the GDP generated from these two districts (in terms of 1987 prices, it is 228076 million TL), but the 1993 GDP did not include these new provinces and declined to 170275 million TL, whereas the GDPs in Ardahan and Igdir were 46485 and 59085 million TL. The alternative to the exclusion of old (mother) provinces from the sample is to calculate the true GDP figures for the old province by adding the GDPs of the new provinces. However, Ardahan and Igdir were exceptions, because they were formed from one city. Most of the new provinces were formed as villages or districts from at least two cities.

12. Our instruments are valid, and our GMM estimator is consistent, because the second-order serial correlations in error terms are low, and we fail to reject the overidentification restriction with the Sargan test $\left(\chi^{2}\right)$.

13. State banks carry large amounts of non-performing loans arising from these operations and the stock of these loans was about $\$ 12$ billion in 1998, almost $5 \%$ of Turkey's GDP (Denizer et al., 2000).

\section{REFERENCES}

Alessandrini P. and Zazzaro A. (1999) A 'possibility' approach to local financial systems and regional development: the Italian experience, in MARTIN R. L. (Ed.) Money and the Space Economy, pp. 95-114. Wiley, Chichester.

Amos O. M. Jr and Wingender J. R. (1993) A model of the interaction between regional financial markets and regional growth, Regional Science and Urban Economics 23, 85-110. 
Arellano M. and Bover O. (1995) Another look at the instrumental variable estimation of error-components models, Journal of Econometrics 68, 29-51.

BARro R. J. (1997) Determinants of Economic Growth: A Cross-Country Empirical Study. MIT Press, Cambridge, MA.

BARRo R. J. and LEE J. W. (1996) International measures of schooling years and schooling quality, American Economic Review 86, 218 -223.

Bencivenga V. R. and Smith B. D. (1991) Financial intermediation and endogenous growth, Review of Economic Studies 58, $195-209$.

Berger A. N. and Deyoung, R. (2001) The effects of geographic expansion on bank efficiency, Journal of Financial Services Research 19, 163-184.

Berger A. N., Miller N. H., Petersen M. A., Rajan R. G. and Stein J. C. (2005) Does function follow organizational form? Evidence from the lending practices of large and small banks, Journal of Financial Economics 76, 237-269.

Black D. and Henderson V. (1999) Spatial evolution of population and industry in the United States, American Economic Review 89, 321-327.

BLUNDELl R. and BOND S. (1998) Initial conditions and moment restrictions in dynamic panel data models, Journal of Econometrics 87, 115-143.

Caselli F., Esquivel G. and Lefort F. (1996) Reopening the convergence debate: a new look at cross-country growth empirics, Journal of Economic Growth 1, 363-389.

Celasun O., Denizer C. A. and He D. (1999) Capital Flows, Macroeconomic Management, and the Financial System: Turkey, 1989-97. World Bank Working Paper 2141.

Denizer C. A., Gultekin M. A. and Gultekin N. B. (2000) Distorted incentives and financial development in Turkey, in World Bank Financial Structure, and Economic Development Conference Papers.

Dow S. C. (1987) The treatment of money in regional economics, Journal of Regional Science 27, 13-24.

Dow S. C. and Rodrigues-Fuentes C. F. (1997) Regional finance: a survey, Regional Studies 31, 903-927.

European Banking Federation (2000) General statistics on the European financial sector as at 31.12.2000 (available at: www.fbe.be $\backslash$ Content $\backslash$ Default.asp).

FAini R., Giannini C. and Ingrosso F. (1993) Finance and development: the case of southern Italy, in GiOvanNini A. (Ed.) Finance and Development: Issues and Experience, pp. 158-213, Cambridge University Press.

GAL Z. (2005) Challenges of the EMUs: spatial structure and the expanding European integration of the Hungarian banking system in the light of the accessions. Conference Paper, 17th Annual Meeting on Socio-Economics.

Gentle C. J. S. (1993. The Financial Services Industry. Avebury Ashgate, Aldershot.

Greenwald B. C., Levinson A. and Stiglitz J. E. (1993) Capital market imperfections and regional economic development, in Giovannini A. (Ed.) Finance and Development: Issues and Experience, pp. 65-98, Cambridge University Press.

Greenwood J. and Jovanovic B. (1990) Financial development, growth and the distribution of income, Journal of Political Economy 98, 1076-1107.

Guiso L., SAPienZa P. and Zinagles L. (2004) Does local financial development matter?, Quarterly Journal of Economics 119, 929-959.

HAO C. (2003) Development of financial intermediation and economic growth: Chinese experience. Paper presented at the First Academic EUDN Conference, Economic Growth, Poverty Reduction and Institutions.

Harrigan F. J. and MCGregor P. G. (1997) Interregional arbitrage and the supply of loanable funds: a model of intermediate financial capital mobility, Journal of Regional Science 27, 357-367.

Hsiao C. (1986) Analysis of Panel Data. Cambridge University Press, Cambridge.

Hutchison R. W. and MCKillop D. G. (1990) Regional sector models: an application to the Northern Ireland financial sector, Regional Studies 24, 421-431.

Hutchison R. W. and McKillop D. G. (1991) Financial intermediaries and financial markets: a United Kingdom regional perspective, Regional Studies 25, 543-554.

Istanbul Chamber of Industry (2004) Turkey's Top 500 Industrial Enterprises.

Karadag M., Onder O. and Deliktas E. (2005) Growth of factor productivity in the Turkish manufacturing industry at provincial level, Regional Studies 39, 213-223.

KING R. G. and LEVINE R. (1993) Finance, entrepreneurship and growth - theory and evidence, Journal of Monetary Economics 32, 513-542.

King R. G. and Levine R. (1994) Capital fundamentalism, economic development, and economic growth, Carnegie-Rochester Conference Series on Public Policy 40, 259-292.

Klagge B. and Martin R. (2005) Decentralized versus centralized financial systems: is there a case for local capital markets? Journal of Economic Geography 5, 387-421.

LEVINE R. (1991) Stock markets, growth, and tax policy, Journal of Finance 46, 1445-1465.

LEVINE R. (1997) Financial development and economic growth: views and agenda, Journal of Economic Literature 35, 688-726.

LEVINE R., LOAYZA N. and BECK T. (2000) Financial intermediation and growth: causality and causes, Journal of Monetary Economics 46, 31-77.

MARTIN R. and MinNs R. (1995) Undermining the financial basis of regions: the spatial structure and implications of the UK pension fund system, Regional Studies 29, 125-144.

McPherson S. H. and Waller C. J. (2000) Do local banks matter for the local economy? In search of a regional credit channel, in Hess G. D. and Van Wincoop E. (Eds) Intranational Macroeconomics, pp. 295-316. Cambridge University Press, Cambridge.

Moore C. L. and Hill J. M. (1982) Interregional arbitrage and supply of loanable funds, Journal of Regional Science 22, 499-512.

MORGAN K. (2004) The exaggerated death of geography: learning, proximity and territorial innovation systems, Journal of Economic Geography 4, 3-21.

Pollard J. S. (2003) Small firm finance and economic geography, Journal of Economic Geography 3, 429-452.

Porteous D. (1995) The Geography of Finance: Spatial Dimensions of Intermediary Behavior. Avebury Ashgate, Aldershot. 
Porteous D. (1999) The development of financial centres: location, information externalities and path dependence, in MARTIN R. L. (Ed.) Money and the Space Economy, pp. 95-114. Wiley, Chichester.

Roberts R. B. and Fishkind H. (1979) The role of monetary forces in regional economic activity: an econometric simulation analysis, Journal of Regional Science 19, 15-29.

Robinson J. (1952) The generalization of the general theory, in RoBinson J. (Ed.) The Rate of Interest, and Other Essays, pp. 67-142. Macmillan, London.

SAint-PAul G. (1992) Technological change, financial markets and economic development, European Economic Review 36, 763 -781.

Schumpeter J. A. (1962) The Theory of Economic Development: An Inquiry into Profits, Capital, Credit, Interest and the Business Cycle. Oxford University Press, London. 